\title{
AOR
}

Selected Papers of \#AolR2019:

The $20^{\text {th }}$ Annual Conference of the Association of Internet Researchers Brisbane, Australia / 2-5 October 2019

\section{TRUST IN TRANSLATION: A CASE STUDY OF COPYRIGHT AS A LEGAL TRANSPLANT IN THE MUSIC INDUSTRY IN MYANMAR}

\author{
D. Bondy Valdovinos Kaye
}

\section{Trust and Transplants}

Trust is foundational in digital governance, especially in regard to fundamental policies that affect how information is regulated online such as copyright. As copyright regulations in developed nation-states rush to keep pace with evolving digital technology, developing nations face pressure to adopt foreign copyright policies as part of international treaties (Yu, 2006). These 'transplanted' policies are often implemented without being adapted to local conditions or critically evaluating their future consequences. This study examines transplanted copyright regulation in an emergent and increasingly digitalized creative industry: the music recording industry of Myanmar. Through qualitative interviews with key stakeholders this study critiques trust in transplanted copyright by asking: Why do musical artists in Myanmar trust transplanted copyright?

Legal transplanting, taking a law or legal framework from a source nation-state and implanting it into a host nation-state, was a common practice throughout colonial history (Watson, 1993). Transplants are still employed in modern international intellectual property governance through multi-lateral treaties such as the Trade Related Aspects of Intellectual Property Agreement (TRIPS) (Yu, 2006). Transplanted copyright has encountered issues in cases where source regulations do not adequately account for local history, culture, and language in host nation-states (Geller, 1994). Despite wide criticism against legal transplants (Legrand, 2002), they remain a fundamental component of globalized governance (Harding and Örücü 2002).

The legal code of Myanmar, formerly Burma and formerly a British colony, was shaped almost entirely by colonial-era transplant laws. The only copyright law enacted in Myanmar was ratified in 1914, transplanted from the UK Copyright Act of 1911. Recently, after several years of development, the Myanmar Parliament passed the Literary and Artistic Copyright Act in 2019 that contains several transplanted provisions that accede to international standards set by the World Intellectual Property 
Organization that will impact, among other things, the music recording industry of Myanmar.

Copyright is fundamental to governing music industries (Wikström, 2019). Over the past two decades, music recording industries have experienced unprecedented disruption resulting from digital music technologies that has required innovative regulatory response. Policymakers in developed nation-states spent the first part of the $21^{\text {st }}$ Century desperately trying to sort out the new copyright challenges connected digital music proliferation. Meanwhile in some developing nation-states, in particular those with unique or informal creative industries, the transplantation of foreign IP regulations have led to new problems and destabilization (Yu, 2006).

\section{Digital Myanmar}

Myanmar has undergone a seismic shift in digital capacity in the past ten years. Prior to 2011, Myanmar's internet penetration rate was one of the lowest in the world. In 2017, the rate skyrocketed to nearly ninety percent coverage following new laws that allowed foreign telecommunications companies to establish new mobile networks in 2012 (Telenor, 2017). Mobile sim cards, which previously could cost up to $\$ 1500$ (USD) in Myanmar dropped to just $\$ 1.5$ (USD) and affordable smart devices have become more available from neighboring China. The availability of the mobile internet has affected several sites of industry in Myanmar; the music recording industry being no exception.

The Myanmar music recording industry has experienced the same digital disruption as in other music industries around the world; however, the Myanmar music industry faces additional challenges. For example, a lack of copyright law gave way to a deeply informal structure, fragmentation, and unique practice of copying international songs and adapting them for Burmese audiences (MacLachlan, 2011). As momentum has built toward the adoption of the 2019 Copyright Law, many artists in press and in interviews expressed a willingness to trust and accept transplanted foreign copyright.

\section{This Study}

Building on legal transplant theory (Watson, 1993) this study takes an interdisciplinary approach to studying trust in transplanted regulation from a decolonizing methodological viewpoint (Tuhiwai Smith, 2008). Data for this study were collected from qualitative interviews with thirty $(n=30)$ key informants in the Myanmar, including music industry professionals and legal experts. Coding of interviews revealed strong favorable attitudes toward transplanted copyright among informants.

Key findings reveal the presence of a strong 'copyright culture' among musical artists in Myanmar. Despite being absent throughout the development of the Myanmar music industry, many musical artist informants expressed favorable attitudes toward the adoption of copyright in Myanmar. On the other hand, producers and industry insiders expressed frustration with the push to transplant foreign systems. Throughout its development, Myanmar music professionals have developed their own solutions to problems that take into account history, culture, and language.

\section{Conclusion}


Formal music industries rely on stakeholders' trust in copyright system. In an informal music industry, like Myanmar, implicit trust in a foreign system could lead to perilous consequences. Transplanted copyright may Myanmar artists at a disadvantage in the digital music economy. Digital regulations for music are increasingly common in other jurisdictions, such as the recent Music Modernization Act in the US and the European Directive on Copyright in the Digital Single Market. However, transplanted Myanmar Copyright Act does not contain specific provisions that reflect recent trends in copyright development for digital music.

This case study raises questions about the international power dynamics that have led to a culture of copyright in Myanmar, in which artists implicitly trust foreign copyright regulation. I argue that global copyright regulation must be viewed through a decolonizing lens (Tuhiwai Smith, 2008). Throughout the past two centuries, copyright has been used as an imperialistic tool. Nearly every critical juncture in the development 'modern' copyright law has coincided with paradigm shifts in politics, technology, society, or norms. At each breaking point, the construction and interpretation of the law has shifted. Yet the sites where these reinterpretations have taken place have been colonial or economic superpowers. These powers created a system of copyright that worked best for them and protected their interests in response to a changing world. It was no surprise, therefore, that nuance would be lost in translation when copyright was transplanted elsewhere in the world. As the next patient on the transplant list, stakeholders in Myanmar should have the same opportunity to provide their input to create a copyright system that fits Myanmar's unique circumstances and is deserving of their trust.

\section{References}

Cheesman, N. (2015). Opposing the Rule of Law: How Myanmar's courts make law and order. Cambridge: Cambridge University Press.

Geller, P. E. (1994). Legal Transplants in International Copyright: Some Problems of Method. UCLA Pacific Basin Law Journal, 13, 199-230.

Harding, A., \& Örücü, E. (2002). Comparative Law in the 21st Century. London: Kluwer Law International.

Legrand, P. (1997). The Impossibility of Legal Transplants. Maastricht Journal of European and Comparative Law, 4, 111-124.

Lobato, R., \& Thomas, J. (2015). The Informal Media Economy. Cambridge: Polity.

Maclachlan, H. (2011). Burma's Pop Music Industry: Creators, Distributors, Censors. Rochester: University of Rochester Press. 
Telenor. (2017). Realising Digital Myanmar: Leapfrogging to an Inclusive Digital Economy. Retrieved from https://www.telenor.com/wpcontent/uploads/2018/02/Telenor-Realising-Digital-Myanmar-Report-06February.pdf

Tuhiwai Smith, L. (2008). Decolonizing Methodologies: Research and Indigenous Peoples. London: Zed Books Ltd.

Watson, A. (1993). Legal Transplants: An Approach to Comparative Law. Athens, GA: University of Georgia Press.

Wikström, P. (2019). The music industry: Music in the cloud (3rd ed.). Malden, MA: Polity Press.

Yu, P. (2006). TRIPs and its Discontents. Marquette Intellectual Property Law Review, 10(2), 369. 